\title{
Genel Felsefe Kaynaklarında Felsefenin Başlaması ve Milet Okulu
}

\author{
The Start of Philosophy in Sources of General Philosophy and \\ The Milesian School
}

\begin{abstract}
Ayşegül DOĞRUCAN *
Öz: Batı felsefe tarihinin başlangıcında yer alan Milet Okulu, başlangıç konumundan dolayı felsefe tarihinde özel çalışmaların da konusu olmuştur. Bu çalışmalar sadece felsefe tarihiyle sınırlı kalmayıp insanlığın düşünsel evriminin açıklanmasını konu edinen farklı alan çalışmalarında da özel bir konu alanı oluşturmuştur. Bilhassa felsefenin ortaya çıkışının koşulları olarak nitelendirilen öğeler, sadece düşünce tarihini yorumlayan bakış açılarından değil, aynı zamanda uygarlıkların ilerleyişine yönelik yaklaşımlardan da etkilenmekte ve bakış açısına dayalı olarak bir kriter halini almaktadır. Felsefenin üzerinde uzlaşılmış tek bir tanımı olmamasına rağmen, ortaya çıkan tek bir felsefe algısı söz konusudur ve bu algının kaynağına da Miletli filozofların özellikleri yerleştirilmiştir. Hayata ve evrene bir bütün olarak bakma çabası olarak gördüğümüz felsefe Milet'le özdeşleşen bu özellikleri taşımakta mıdır? Bu doğrultuda çalışmanın amaçlarından biri, Milet Okulunun öneminin yorumlanış şekillerinin beraberinde farklı yaklaşımları ya da tavırları getirip getirmediğinin tespit edilmesidir. Bir diğer amaç ise, Milet Okulu özelinde yapılan tanımların, felsefenin ve kültürlerin bugün içinde bulunduğu durumla uyuşup uyuşmadığını incelemektir. Bu amaçlar doğrultusunda farklı geleneklerden gelen felsefe tarihi kaynakları ve diğer ilgili kaynaklar taranmış, felsefenin başlangıcı ve Milet Okuluna bakışları ve değerlendirmelerinin benzerlik ve farklılıkları değerlendirilmeye çalışılmıştır.
\end{abstract}

Anahtar sözcükler: Felsefe, Milet Okulu, Bilim, Din, Mit

Abstract: The Milesian School has been the subject of various specific studies in the history of philosophy as the starting position for the history of western philosophy. These studies are not limited to the history of philosophy and they also constitute a specific subject area for the studies of various fields that focus on explaining humanity's evolution of thought. In particular, those elements that are defined as the conditions for the emergence of philosophy are not only affected by the perspectives that interpret the history of thought, but also, by the approaches concerning the progress of civilizations and are becoming a criterion based upon the point of view. Although there is no single definition agreed upon on the philosophy, there is a single perception of philosophy that emerged, and the properties of the Milesian philosophers are placed at the center of this perception. Does the philosophy, which we see as the effort to look at life and the universe as a whole, carry the properties identified with the Milesians? Within this scope, one of the goals of this study has been to determine whether the ways of interpreting the significance of Milesian School bring along various approaches or attitudes. Another goal is to examine whether the definitions made on the subject of the Milesian School comply with the condition of philosophy and cultures today. In parallel with these goals, the sources on the history of philosophy from various traditions, as well as other related sources, have been examined, and the attempt has been made to evaluate the similarities and differences, in addition to their points of view and the evaluations made concerning the beginning of philosophy and the Milesian School.

Keywords: Philosophy, The Milesian School, Science, Religion, Myth

\footnotetext{
* Dr. Öğr. Üyesi, Akdeniz Üniversitesi Edebiyat Fakültesi Felsefe Bölümü, ayseguldogrucan@akdeniz.edu.tr, https://orcid.org/0000-0002-0735-9281
} 


\section{Giriş}

Genelde bütün felsefe literatürleri ilk filozoflar kimdir sorusuyla başlar. Batı felsefe tarihinde ilk filozoflar ve aynı zamanda "doğa filozofları" olarak karşımıza Milet Okulu çıkar. Bugün modern manada kullandığımız birçok kavram ve kriterin tarihi seyrinin başlangıcı Milet okuluna dayandırılır. Başlangıç motifi olarak Milet Okulu, istemli ve sistemli bir düşünce tarzının ilk örneği olarak, sistemli insan düşüncesi ve bilgisinin evrim sürecinin başlangıcına koyulmakla birlikte, bu başlangıç politik bir simge haline de dönüşmüş ve kullanılmıştır. $\mathrm{Bu}$ okul ve üç filozofu, bilhassa modern dönemlerde, ulus devlet bilincini güçlendirmek için yapılan her türlü tarih yazıcılığının ve Doğu-Batı karşıtlığında bir üstünlük simgesi şeklinde kullanılmasının sonucu olarak, bir mucize şeklinde yorumlanmış ve bu yorumlamayla tartışmaların da odak noktası olmuşlardır. Yine tartışma merkezlerinden birisi, bilim-din karşıtlığının yorumlanışında kendini göstermektedir. Çünkü Milet Okulunun ortaya çıkışı aynı zamanda aklın ve bilimsel merakın dine karşı zaferi olarak görülmektedir.

Miletli filozoflar, Batı felsefesi tarihinin belki de başlangıcında konumlandırılmalarından belki de henüz tanımların yapılmadığı bir dönemde düşünmüş olduklarından üzerine en çok konuşulan, konuşulmasa bile değinilen ya da "ta Thales'ten bu yana" denilerek anılan filozoflardır. Felsefe tarihi metinlerinin kronolojik zorunluluğu bir kenara birakılırsa, Miletli filozofların belli başlı konularda modern dünyanın atıf ve köken kaynăğ olduğu görülür. Bunlardan ilki hemen herkesin malumu olan ve "Yunan Mucizesi" tabiriyle anılan ve rasyonelbilimsel düşünceyi Batı medeniyetinin köklerine yerleştiren görüş ve beraberinde getirdiği tartışmalardır. 19. yüzyılın tarih yazıcılığının, sosyal bilimlerin kaynak araştırmalarının ve Aydınlanma fikrinin rasyonellik arayışının bir neticesi olmakla birlikte, değişen dünya düzeninde, Batının diğer kültürlere yönelik, her alanda yayılmacı ve dayatmacı tavrını meşrulaştırmak için diğer kültürlerin felsefi düşünceye katkılarını yadsıyan, hatta yok sayan bir dayanak yarattığı düşünülmüş ve haliyle "Yunan Mucizesi" görüşü sorgulanmaya başlanmıştır.

$\mathrm{Bu}$ tartışmanın haklı ya da haksızlığı başka bir incelemenin konusu olmakla birlikte, Milet Okulu ve devamındaki geleneğin algılanışına kaynaklarla bakmak, bize hem tartışmanın genel tablosunu hem de bu okulun modern sürece kadar neden daimi bir atıf odağı olduğunu anlamak açısından faydalı olacaktır.

\section{Felsefenin Ortaya Çıkışı ve Yunan Mucizesi}

Yunan Mucizesi tanımlamasının modern tarih yazıcılığıyla bağlantılı olduğu düşünülür. Aslında "Yunan mucizesi" tartışmasının merkezini doğrudan yakın asırlara tarihlemek doğru değildir. Çünkü bu fikrin geçmişi daha eski kaynaklara kadar uzanmaktadır. Bilindiği gibi bizim doğa filozoflarına ilişkin derli toplu ilk bilgi kaynağımız ve hatta daha detaylı bir incelemeye girdiğimizde, felsefeyi tanımlama çabamıza ilişkin yaklaşımımızın da kaynağında Aristoteles'in Metafizik adlı eseri vardır. Aristoteles (MÖ 384-322) Metafizik'te, felsefenin mahiyetini ve kime bilge denilebileceğini, ilk nedenler üzerinden belirledikten sonra, bu tarz bir felsefenin kurucusunun Thales (MÖ 624-546) olduğunu söyler (Aristoteles 1996, 1). Diogenes Laertius (MS III. yüzyıl) ise kitabın başlangıcında, felsefenin başka kültürlerde başlatıldığına dair anlatıları vererek, felsefeyi başka kültürlere mal eden tavrı eleştirir:

\footnotetext{
"Ama bunlar Hellenlerin başarılarını barbarlara mal ettiklerinin farkında değiller: oysa yalnız felsefe değil, aynı zamanda insan soyu da onlarla başlamıştır........ Böylece felsefe Hellenlerde başlamıştır, zaten felsefe adının da barbar bir sözcükle ilişkisi yoktur" (Laert. 2013, 1314).
}

Hatta bugün felsefenin ortaya çıkışını anlatmak için kullandığımız, birçok kaynakta felsefi 
düşüncenin ortaya çıkışındaki mucizeviliği ya da tarihsel kırılma olmasının nedenini açıklamak için kullanılan "mitolojik, inanca dayalı söylencelerden uzak bir açıklamaya yönelmeyi" de Laertius'da net bir şekilde görebiliriz: "Felsefenin bulunuşunu barbarlara yakuştıranlar, bir de Trakyalı Orpheus'u ileri sürüp onun en eski filozof olduğunu söylerler. Ama ben tanrlar hakkında böyle şeyler anlatan kimseye filozof demek gerekir mi, bilmiyorum” (Laert. 2013, 14) ve bu ifadelerden sonra hangi toplumda kimlere hangi nedenden bilge dendiğini aktarır. Daha sonra da ilk "bilge" olarak Thales'ten bahseder. Laertius'un eserinin, felsefe tarihine ilişkin en eski kaynaklardan biri olduğu düşünülürse, modern dünyanın felsefe tarihçilerinin de bundan etkilenmiş olması elbette muhtemeldir ve doğaldır. Nitekim Ahmet Arslan da felsefenin kökeni konusunda Laertius'la benzer bir açıklama yapar ve kelimenin hem Batı hem de İslam dünyasına Hellence'den geçtiğine işaret ederek, kelimenin kökenine dayalı olarak, felsefenin Hellen kaynaklı bir etkinlik olduğu sonucuna varır (Arslan 2002, 265).

Yine başucu kaynaklarından olan Walter Kranz'in (1884-1960) Antik Felsefe eserinde, dünyanın doğuşuna ilişkin eski öğretilerde, mitolojik öğretilere birçok uluslarda -Babil, Finike, Yahudi, Pers, Eski Türklerde- rastlanıldığı (Kranz 1994, 11) söylenirken, Miletli Filozoflar bölümünde, Milet'i "bilimsel felsefe"nin doğduğu yer olarak ifade eder. Bu doğuşu da coğrafyanın özelliğine bağlar ve felsefenin doğuşunun vazgeçilmez koşullarından birini de bu vesileyle zikreder: "Helenlerle Helen olmayan halkın yanyana yaşayışının ayrı kuvvette bir fikir yarattı̆̆ ve ruha pek ayr bir canlılık verdiği bu yerde ........,pratik yarar için değil de, sadece doğru uğrunda sorularla boğuşmuştur" (Kranz 1994, 27). Böylece felsefe sadece Milet'te başlamakla kalmaz aynı zamanda o başlangıcın "bilimsel" oluşu ve pratik kaygılardan azatlığ da belirlenmiş olur.

Zeller (1814-1908) de Grek Felsefesi Tarihi'nde benzer bir tutuma sahiptir. Zeller felsefeyi Hellas'ta ortaya çıkaran ana unsurun onların sorgulayıcı doğaları olduğunu söyleyerek aynı zamanda, felsefenin neden diğer kültürlerde değil de Hellas'ta ortaya çıktığı sorusunu da cevaplamış olur. Yine bu bakışla felsefe, bir toplumda vücuda gelen ve etkin olan her türlü değerler sisteminin de tartışılıp, bunlar karşısında düşüncenin bağımsızlığının kazanılması anlamina gelir:

"Bir halk hiçbir zaman kendi doğasını, husule getirdiği müesseseleri,
ahlak ve âdetlerini Hellenlerden daha büyük bir tarafsılıkla
yargılamamışlardır. ....... Insan için felsefi düşüncenin özgürlügünü ve
bağımsızlığını kazanan, aklın muhtariyetini ilan edip ona çift yönlü
uygulama alanı kazandıran Hellenlerdi" (Zeller 2017, 31-32).

Felsefenin başlangıcına ilişkin bu yaklaşımlar, zamanla sorgulamaları, olumsuz yaklaşımları ve tepkileri de beraberinde getirmiştir. Bu tepkilerin, akademik olarak haklılığı ya da haksızlığ1 meselesi, daha detaylı çalışmaların ardından varılabilecek bir hükümken, açık olan şey, konunun pratiğe yansımasında bir "ötekileştirme” ye sebep olmasıdır. Bilim ve teknolojinin gelişmesi ve bu gelişimin sosyal bilimlerde yeni arayışları ortaya çıkarması, toplumun da bilimle ve bilimsel gelişmelerle belirlenmesi çabalarına dönüşmüştür. Bu çabanın bir sonucudur ki, "Pozitivizm İlmihalini" yazan Auguste Comte (1798-1857) toplumu ve toplumları bu bilimsellikle belirlemiştir. Comte'un bu belirlenimi, toplumu evrimsel bir süreçte ele almakta ve üç hal yasasıyla açıklamaktaydı. Bu yasaya göre, ilk evreden üçüncü evreye ilerleyen süreçte, üçüncü basamağa ilk ulaşan, bu yasa gereği, zorunlu olarak diğer toplumlardan hep önde olacaktı. Bu zorunluluk ve -bilinçli ya da bilinçsiz- pratikte kabulü, "geri toplumlar" belirlenimini beraberinde getirmiştir. Bütün bunlar, hepsi birlikte, farklı kültürlerde deyim yerindeyse bir savunma halini yaratmış ve bu savunmanın da odak noktası yine felsefenin başlangıcı olmuştur. Hatta bu savunma bazen uç noktalara varmış, felsefenin kökeninin Yunan dışında olduğu ve 
Yunan'ın zaten var olanı "çaldığı" ve "geri kalmışlık" vb tanımlamaların da bu hırsızlık sonucu ortaya çıktığı dahi iddia edilmiştir. George M. James'in (1893-1956) "Çalınmış Miras" adlı eseri tam da bu içerikte hazırlanmıştır. Hatta James, bu durumun -belki de uç noktada- bir sonucu olarak "Yunan felsefe dramast ile işbirliği içinde olan modern kilise" (James 2010, 180) tanımlamasıyla bunu misyonerliğe bağlamış ve bu politikaya "siyahi halkların saygı göstermeyeceğini" deklare etmiştir. Anlaşılacağı üzere felsefenin kökeni problemi, sadece bir başlangıç araştırması olmaktan çıkıp bir ırkın başka bir ırka üstünlüğünün gerekçesi şeklinde yorumlanmaya ve mazi sorgulaması üzerinden "kurtuluş felsefesi” tesisine kadar gitmiştir:

"Yunan felsefesinin yazarlarl Yunanlar değil, Kuzey Afrika'nın Siyah halkl, Misırlılar idi” (James 2010, 176). "Bu sav, bir inanç olarak kabul edip ona uygun yaşadıklarında, tüm Siyah halklar için bir kurtuluş felsefesi olacaktır" (James 2010, 177).

Elbette bu durum G. G. M. James'in duygulanımları üzerinden yaptığı, dolayısıyla objektif olmayan bir değerlendirme şeklinde yorumlanabilir -belki aksi de savunulabilir-. Ancak bu yorumlama tarzı da mevcut konu üzerinden uç noktada değerlendirmeler olduğu gerçeğini değiştirmez. Kaldı ki sorun, çok eski bir tarihi işaret ettiği için bu konuda hakikati bulmak da zorlaşmaktadır. Bu zorluk, felsefenin başlangıcı olarak belirlenen tarihte yazılı geleneklerin yeni yeni yayılmaya başladığı bilgisiyle de birleşince, mesele yazılı gelenek sözlü gelenek ayrımının bir sonucu olarak da görülebilmektedir. Nitekim Miletli filozofların düşünce tarzının onlardan önce mevcut olduğuna dair elimizde yazılı kayıtlar mevcut olmadığından kontrol etme ya da doğrulama şansı da yoktur. Bu çerçevede "söz uçar yazı kalır" düsturu, tarihsel bir gerçeklik olarak karşımıza çıktı̆̆ 1 gibi, kültürle de yakından ilişkili olan felsefenin sözlü geleneklerdeki konumu yine bir problem olarak karşımızda durmaktadır.

Cevizci (1959-2014), Yunan felsefesinin doğuşundan sonra onu diğer felsefelerden ayıran belki de en önemli şeyin "yazılı gelenek" olduğu tespitini yapar (Cevizci 2009, 31). Yunanlıların başka uygarlıklara olan kültürel borçlarından bahseden Cevizci, "Yunan hiçbir şekilde bir mucize değildi; o, tarihin vücut verdiği hoş bir tesadüf ve komşularla daha önceki kültürlerden alınan değerli derslerin bir ürünüydü" (Cevizci 2009, 27) sonucuna varır. Bu sonuç haklı görünmektedir, çünkü haksız olduğu varsayıldığında, Yunan felsefesinin ana önermelerinden olan "nihil ex nihilo fit" önermesinin, tarihte gerçekleşmiş olduğunu, hem de Yunan düşüncesi lehine gerçekleşmiş olduğunu kabul etmek gerekir. Wilhelm Capelle (18711961) de böyle düşünmüş olacak ki, “...bizi hâlâ şaşırtan dahicesine bilimsel görüşler ağır basmaktadır, hele Ioniaların, insanlığa kendilerinden önce kimsenin adım atmadiğ gerçek bilgi yolunu ilk kez açtıkları düşünülürse! Önceki kuşakların bize aydınlattı̆̆ karanlıkları onlara kim aydinlatmıştı?" diye sorar (Capelle 2011, 15). Capelle bu noktada "Grek Felsefesinin Önöyküsü” olarak “”’Evrendoğum Rapsodları ve Düzyazıları” alır. Capelle'de ilk filozoflardaki özgünlüğü teyit ettikten sonra, bireysel üsluplarının parlak örneklerinin "düz yazı" ile sunulmasını da ekler. Düz yazının en eski temsilcileri, yani kurucuları (Capelle 2011, 16) dediği Grek filozofların, sadece felsefe sorunlarını fark etmekle, kavramakla kalmayıp, hissettiklerini, cevap bulmayı kendilerine göreve edindiklerini, "buldukları çözümlerin doğruluğu ve bilgilerinin hakikiliği konusunda en ufak bir kuşkuya kapılmadıkları için de bunları yurttaşlarına -yazllı olarak- açıklamaktan çekinmemişlerdir" (Capelle 2011, 16-17) diyerek, hem yazılı geleneğe vurgu yapar hem de bu yazılı geleneğin bir özgüven gerektirdiğine işaret ederek farklı bir yorum da getirir. Bu yorum yukarıda bahsettiğimiz Zeller'in görüşünü de destekler niteliktedir. Çünkü yerleşik geleneklerin, inançların hâkim olduğu bir ortamda, farklı düşüncelerin hem beyan edilmesi hem de yazılı hale getirilerek kalıcılığının sağlanması özel bir durumdur. Capelle, Zeller ve benzer felsefe tarihçilerinin bu vurgusu elbette sebepsiz değildir. 
Tarihte, fikirleri dönem düşüncesine uymadığı için yadırganan, dışlanan, sürgün edilen ve hatta öldürülen karakterler olduğu gibi, düşüncelerin yayılmasını engellemek için yazılı kaynakların yasaklanması, saklanması ve yakılması da vakıalar arasındadır. Hal böyle iken, genel karakteristikleri özgür ve farklı düşünme olan felsefe için hem beyan etme hem de yazılı kaynak oluşturma ayırt edici ve özel bir durumdur tespiti haklı görünmektedir.

Konuya bir başka yaklaşım ise, felsefenin bir anlama çabası olarak tanımlanmasının ardından, bu tanımlamanın koşulu olarak belirlenen dil-düşünce ilişkisiyle bağlantılıdır. Burada da yazılı geleneğin oluşması ve tarihi kaynağa dönüşmesi kendini gösterir. Ancak diğer yaklaşımlardan biraz farklı olarak, bu yaklaşım felsefenin başlangıcını daha eski tarihlere götürür. Aksi bir bakış açısı insanın çevresini ve kendisini anlama çabasını yalnızca "modern" insana yükler ve modern köklerinden uzak insanın düşünmeden azat ve uzak olduğunu kabul etmek zorunda kalır. Bu ise kültürel bir evrimin varlığ 1 gerçeğini yadsımak anlamına gelir. Dolayısıyla burada ön plana çıkan ve bir kriter olarak belirlenen, Störig'in (1915-2012) ifadelerinden de anlaşılacağı üzere, bizzat yine kaynakların kendisi olmaktadır:

"Felsefe, varoluşun -hem diş dünyanın ve hem de insanın iç dünyasınıngizini, düşünerek çözme uğraşı olarak tanımlanırsa, bize kalmış olan bütün yazllı belgelerden çok daha eski bir tarihte başlamış olmalıdır. Felsefeyle uzaktan yakından ilişkilendirebileceğimiz belgeler ise en çok 3000 yll öncesine iner" (Störig 2000, 18).

Störig'in bu bakış açısını geliştirmesinde, yaşadığı çağın etkisi olduğunu söylemek sanırım yanlış olmayacaktır. Felsefede, daha antikçağda "doğru bilgi mümkün müdür?" sorusunun gündeme gelmesi epistemolojik çalışmaları meşgul ederken, modern bilimin gelişmesiyle birlikte, sorun felsefi önermelerin doğruluğu özeline kaymıştır. Felsefi önermelerin doğruluğunun tespit edilebilmesi için, bilimde olduğu gibi deney ve sinama yöntemlerinin mümkün olmaması, metafizik ve değerler alanına ilişkin felsefi önermelerin yeniden sorgulanmasına neden olmuştur. Bu durum bir taraftan kesin sonuçlara imkân vermemesinden dolayı metafiziğin elenmesini ve yadsınmasını getirirken, felsefe alanında asla yadsınamayacak olan etik, estetik vb. problemlerin doğruluğu başka mecralarda aranmaya başlanmıştır ve düşünceyle de sıkı bağıyla ele alınan dil ön plana çıkmıştır. Dil-düşünce ilişkisi açısından bakıldığında ve ikisinin birbirini geliştirici boyutu dikkate alındığında, evrene, hayata ve insana dair bir düşünce etkinliği olan felsefenin de dille başlatılması mümkün olmaktadır. Yine aynı dönemde bilimin, değerler alanına ilişkin sorunları çözmediği gibi, sebep olduğu toplumsal sonuçlarla yeni tartışmaları ve değerler problemini de gündeme getirmesi, felsefi problemlerin ya da tavrın bilimsel tavırla özdeş görülmemesini anlamlı kılmaktadır.

Farklı bir bakış açısıyla George Thomson (1903-1987), 'Yunan Sözbiliminin Kökenleri' bölümünde, Yunan söz dünyasındaki etkileri incelerken, Cornford'un içerik ve Norden'ın ise biçem yönüyle Yunan düşüncesini incelediğini ancak her ikisinin de "Yunan felsefesinin köklerinin Yakındoğu'nun eski dinlerinde bulunduğu" sonucuna ulaştı̆̆ını söyler (Thomson 1997, 143).

Antik Yunan felsefesiyle ilgili bir yaklaşım ise, Friedrich Nietzsche'ye (1844-1900) aittir. Nietzsche, felsefenin ortaya çıkışından, çağdaşlarının "Asya ve Mısır kökenli ithal bir bitki" (Nietzsche 2018, 83) şeklinde bakabildiğine gönderme yapar. Genel kanaat ve tavırda Antik Yunan'ı tanımanın felsefenin nasıl ortaya çıktı̆̆ını anlamamıza yardım edeceği yönündeyken, Nietzsche bunu felsefenin değil filozofun nasıl sivrildiğine bakmanın Yunanlıları anlamamıza yardımcı olacağını söyler (Nietzsche 2018, 84). Yine Yunan'da ortaya çıkan filozof tiplerinden yola çıkarak, bu tarz bir çeşitliliğin Yunanlılara ait olduğu ve bu aitlikle "bu zenginlikle Alman'lar bile boy ölçüşemez" diyerek diğer halklardan ayrıldığı tespitini yapar (Nietzsche 
2018, 84). Ancak Nietzsche filozofun apansız ortaya çıkışını kabul etmez:

"Yunanlar, Miletoslu Thales'e ilk filozof gözüyle bakarlar. Ondan önce filozof bulunmadiğını söylemek kadar şu ya da bu ismin ilk filozof olduğunu söylemek de keyfídir. Çünkü bir <filozof> tipi apansız ortaya çıkmaz" (Nietzsche 2018, 95).

$\mathrm{Bu}$ örnekler çoğaltılabilir ya da farklı açılardan yeni örnekler eklenebilir. Hangi pencereden bakılırsa bakılsın, buradaki esas durum, tarihin tekrar edilememesi ve söz konusu tarihin bugünden uzaklığı ve koşulları, yorumları doğrulama ya da yanlışlama olanağını vermemektedir. Dolayısıyla mevcut hal, düşünce tarihçisinin bakış açısına, beklentilerine ve belirlendiği diğer unsurlara göre bir şekle bürünebilmektedir. Bununla birlikte, Milet Okulunun felsefenin başlangıcında olmasına dair görüşün sorgulanmasının nedeni yalnızca kültürler arasında yaşanan bir rekabette, bir üstünlüğün dayanak noktası olması değildir; aynı zamanda Aristoteles'ten beri süregelen felsefe tanımlarının, bugünün felsefi araştırmalarında özellikle ontoloji düzleminde karşılık bulmamasının bir sonucudur. Bilimlerin gelişimi ontoloji çalışmalarını âtıl bırakmış, felsefe genel olarak değerler ve dil alanında ya da yapısı gereği değişen gelişen (!) dünyaya bir üst bakış sunmaya başlamıştır. Başka bir ifadeyle değişen dünyanın değişen ihtiyaçları, felsefeyi Milet’te başlatan ve bir düşünceyi felsefe olarak belirlediğimiz unsurları sorgulatır hale gelmiştir. Bu felsefenin doğasıyla alakalıdır. Soccio'nun (1946-) da dediği gibi "Kendi kültürel sinırlart ve önyargılart içinde bile felsefe, belki de bütün disiplinler arasında en "serbest" olanıdır" (Soccio 2010, 39). Bu serbestlik özellikle günümüz koşullarında kendini daha çok hissettirmekte ve benzerlik ve farklılıkların yorumlanmasını güçleştirmekte ve güçlügü aşmak için başlangıca dönme, başlangıç unsurlarını sorgulama ihtiyacını da beraberinde getirmektedir. Bu başlangıç unsurlarının sorgulanması ise, başlangıç fikrini de sorgulamamıza neden olmuştur. Bu noktada Milet Okulu'nun genel görüşlerine ve günümüzde hangi alanda köken arayışına kaynak olduklarına bakmakta fayda vardır.

\section{Miletli Filozoflar- Felsefe ve Merak}

Miletli filozoflar sordukları sorular ve cevaplarıyla, içinde bulundukları çağda salt merakın doğasını temsil etmeleriyle felsefenin başlangıcı olarak kabul edilirler. Çünkü evreni anlamaya yönelik teorik bir faaliyetin kayıtlı ilk örneği orada görülür. Aslında evrene, hayata ve her şeyin anlamına yönelik sorgulama insanlığın kayıt bulunmayan tarihlerine kadar götürülebilir. Doğa karşısında "akı1" dışında belirgin bir yetiye sahip olmadığı göz önünde bulundurulduğunda, onun düşünsel evriminin varoluş süreciyle eş zamanlı olduğunu düşünmek mantıksız görünmemektedir. Buna ek olarak Miletlilerle yakın zamanlarda yaşamış ve yine bir anlama çabasıyla hareket eden isimler de görmek mümkündür. Nitekim Hint’te, Çin'de, İran'da buna benzer isimlere rastlamak mümkündür. Hatta yeni felsefe tarihi çalışmalarında da dikkat çekmektedir bu isimler. Elbette bu isimlerin yeni kuşak çalışmalarda dikkat çekmesi de sebepsiz değildir. Bu yeni tavır, kaynağını Milet’te bulan modern Batı dünyasının hezeyanlarının bir sonucu olarak da görülebilir. İyon coğrafyası dışında aranan bilgelik şekilleri, belki de içinde gizil olarak, günümüz dünyasını yaratan süreci sorgulayan bir memnuniyetsizliği de içeriyordur ve eğer böyle bir memnuniyetsizlik söz konusuysa, sorunun aydınlatılması, modern Batı dışında kalanlar için tarihsel, kültürel bağlamda anlam kazanacaktır.

Felsefenin başlangıcına yönelik bakışların asıl odak noktası, bugünün kaynaklarına ulaşma çabasıdır. Nitekim W. K. C. Guthrie (1906-1981), Ilkçăg Felsefesi Tarihi kitabının başında, çalışmanın ne için ve nasıl yazıldığını ve Yunan felsefesine duyulan ilgi ve meraka dayalı varsayımını açılarken, sanki bu dinleyici/okuyucularda bu çabayı sezmiş gibidir:

"Bu konuşmalar boyunca, onlara Yunan düşüncelerinin daha 
sonraki Avrupa düşüncesinin temelinde bulunduğu izlenimini vermiş, ve bunun sonunda onlarda, bu Yunan düşüncelerinin, herşeyin ötesinde, gerçekte ne olduklarını daha kesin olarak bilme isteği uyandırmıs olduğu varsayıldl" (Guthrie 1999, 7).

Kökenlerini anlama çabası, diğerlerini -“ötekileri” anlayarak kendi farkına 1şık tutma kaygısı, dünyayı bir bütün olarak anlama çabası, -kökenlerin neticesinde mevcuda gelen- bugün için başka bir seçenek olamaz mıydı, gibi sorularla dikkatler Milet ya da daha geniş olarak İyon coğrafyasında felsefeyi yaratan koşullara yoğunlaştı ve bu da karşılaştırmalı incelemeleri beraberinde getirdi. Söz konusu incelemeler, aynı zamanda felsefenin neliğinin belirlenmesine ve bugünün koşullarında yeniden belirlenmesine ya da en azından yeniden sorgulanmasınaimkân sağladı.

Hayata dair merak, evrenin başlangıcına ilişkin sorular, nasıl yaşanmalı vb sorular yukarıda da belirttiğimiz gibi hep vardı. Konfüçyus'un, Buda'nın, Lao Tzu'nun, İşaya'nın yaptıkları da bir tür sorgulamalardı Hatta çok daha öncesine gittiğimizde ilk inanç sistemleri de bütün dini sistemlerde olduğu gibi hayatın anlamına ilişkin bir inanç dizgesi (Runzo \& Martin 2002, 27) ve hayatı, hayatın başlangıcını anlama gayretlerinin bir sonucundan başka bir şey değildir. Nitekim Hz. İbrahim'in Tanrıyı arayışı da benzer bir sorgulama mantı̆̆ına sahiptir (En'âm, 76-79). İbrahim'in kendi varlık sebebi olarak bir yaratıcı araması ve bu arayışta tükenen ve batan şeyleri eleyerek, her türlü somut ve soyut olandan, değişen ve tükenenden azade bir yaratıcı olması gerekliliğine sürükleyen düşünce süreci, insanın varoluşun başlangıcına dair bir araştırmayı işaret etmektedir. Ancak Antik Yunan'da bu tavır politeist bir tavrın monist "arkhe" arayışına dönüşüp, beraberinde fizik dünyanın bilgisine yönelik bir araştırmayı getirirken, diğer coğrafyalarda meselenin teolojik, ahlaki ve toplumsal düzlemde kalmasıyla ayrılır. Bu ayrım noktas1 "Yunan insanının sezgi gücü” olarak yorumlanmıştır. Örneğin Çiğdem Dürüşken’e göre, henüz daha felsefe ortaya çıkmadan, soyut düşüncenin henüz gelişmediği mitolojik döneminde "Yunan insan gelişkin bir merak duygusuna ve yüksek sezgi gücüne sahip olduğundan" doğanın görünmeyen yüzünü merak etmiş ve "Evrenin kökeni nedir?" şeklinde "oldukça naif" bir soru sormuştur ve mitolojik dönemde (Theogonia'da) kaos olarak cevaplanan bu soru, Miletli filozofların "arkhe nedir" sorusuna, deyim yerindeyse, modellik etmiştir (Dürüşken 2013, 19).

Önceki bölümde de bahsettiğimiz gibi modellik mevzusu ya da etkilenme konusu yazılı kaynaklar 1şı̆̆ında ancak mevcut haldeki kadar aydınlatılabilmektedir. Yine buna benzer şekilde Antik Yunan felsefesi söz konusu olduğunda başlangıç noktasında belirlenen unsurlardan biri "hayret" ve "merak"tır. İnsanın evren ve hayat karşısında yaşadığı hayret duygusunun, beraberinde merakı ve dolayısıyla felsefeyi getirmesini ifade etmektedir. Bu açıklama modern bir açıklama olmaktan ziyade, kaynağını hem bir filozof hem de felsefe tarihinin ana kaynaklarından olan Aristoteles'ten almaktadır:

\section{"Çünkü şimdi olduğu gibi başlangıçta da insanları felsefe yapmaya iten şey, hayret olmuştur. Onlar başlangıçta açık güçlükler karşısında hayrete düşmüslerdir. Daha sonra yavaş yavaş ilerlemişler ve ay, güneşe yıldızlara ilişkin olayları, nihayet dünyanın oluşumu gibi daha büyük sorunları ele almışlardır" (Arist. Metafizik 82-83).}

Hayret ve merakla ilgili konuda tıpkı diğer konular gibidir. Ancak burada yapılmaya çalışılanın felsefi tavrı belirleme çabasıyla alakalı olduğunu belirtmekte fayda var. Elbette tıpkı diğer konu başlıklarında olduğu gibi, merak ve hayret de sadece Yunanlılara özgü değildi. Başka toplumlarda da hatta belki de topluluk yaşantısı öncesinde de vardı. Ancak buradaki merakın 
felsefi düşünce ve bilimin kapısını aralayan, özel bir merak olduğu anlaş1lıyor. Nitekim Dumont (1933-1993), felsefe öncesi özdeyişler ya da aforizmalar üzerine kurulu bilgelik kültüründen bahsederken felsefeyle olan ayrımını da yine merak üzerinden yapmaktadır:

"Bu özdeyişler, kallp sözler ya da sloganlar, bir süre sona, felsefi sorgulamaya yol açacak olan ciddi bir meraktan çok, ahlak ve kamusal düzen kaygisindan gelir" (Dumont 2007, 15).

Dumont da felsefenin başlangıç noktası olarak "merak" ancak sorgulamaya imkân sağlayan her türlü "pratik" kaygıdan uzaklaşmış bir tavrı merkeze koymuş görünmektedir. Ancak burada gözden kaçırılmaması gereken bir konuya dikkat çekmekte fayda vardır. Söz konusu felsefe tarihi literatürü elimizdeki sınırlı yazılı kaynak ve aktarımlar üzerinden yapılan yorumlarla şekillenmektedir. Örneğin ana kaynaklar arasında önemli bir yere sahip olan Aristoteles'in burada kendinden önceki filozoflara ve görüşlerine yer veren bir çalışma yaptı̆̆ 1 ve deyim yerindeyse ilk profesyonel tanımlama ve belirlenimleri de yapma imkanına sahip olduğu bir vakıadır. Burada düşünce tarihi açısından dikkat çeken bir başka nokta, yukarıda da bahsettiğimiz felsefenin başlangıcı olarak belirlenen isimdir/isimlerdir. Aristoteles Metafizik'te kendinden öncekilerden bahsederken Thales (MÖ 624-546) ve Anaksimenes'i (MÖ 585-525) başlangıç olarak konu boyunca anmaktadır. Bildiğimiz üzere Milet Okulu üç fillozoftan oluşmaktadır. Thales ve Anaksimenes'i tekrar tekrar anan Aristoteles, "apeiron"u anmakla birlikte Anaksimandros'u (MÖ 610-546) ilk olarak 486. sayfada anmaktadır. Laertius ise felsefenin, Anaksimandros ve Pythagoras (MÖ 570-500) olmak üzere iki başlangıcı olduğunu söyler (Laert. 2007, 17). Laertius da "şimdi doğrudan doğruya filozoflarl ele almalıyı, ilk olarak da Thales ' $i$ ” (Laert. 2007, 19) diyerek Thales'i kabul eder. Çelişik görünen bu durum, daha önceki açıklamalarında yaptığı tanımla belki aş1labilir: "Eskiden 'bilgelik' deniyordu, bunu meslek edinene ve zekasını büyük bir özenle bu konuda çalıştırana 'bilge', bilgeliği bağrına basana da 'filozof' deniyordu”' (Laert. 2007, 16-17). Anlaş1lacağı üzere Laertius bilge ve filozof ayrımını dikkate almakla birlikte, bilgeliği bağrına basan felsefeye de biri İyon diğeri İtalya olmak üzere (Pythagoras'ın uzun süre İtalya'da felsefe yaptığını gerekçe göstererek) coğrafi iki başlangıç göstermektedir. Bizi bu noktada ilgilendiren çelişik durum, salt merak ve mistik öğelerden bağımsızlaşma şeklinde ortaya çıkışını belirlediğimiz felsefenin İyon ve İtalya coğrafyasında -Laertius'un belirlenimiyle- aynı özelliklere sahip olmamasıdır.

Yine Milet okuluyla en çok bahsedilen konulardan biri, Milet Okuluyla birlikte, düşüncenin "inançtan, mitlerden, masallardan" kurtulduğudur. Çalışmanın bu noktasına kadar ki verdiğimiz felsefe tarihi örneklerinden de anlaşılacağı üzere, Miletli üç filozofun mitolojik inançlardan bağımsızlaşarak, rasyonel ve bilimin atası sayılabilecek bir yaklaşımla evreni açıklama gayretinde oldukları vurgusu baskındır. Nitekim, Thales ve Anaksimenes'in değişenlerin ardında değişmeden kalan ve her şeyin dayanağı olan archesi su ve hava maddi ve gözlemle elde edilecek unsurlar olduklarından bu tavra dayanak oluşturmaktadır. Anaksimandros'un apeiron'u ise belirsiz sıfatından dolayı her ne kadar tartışmalara neden olsa da, yaşamın ortaya çıkışını açıklayış tarzı günümüz Evrim Teorisi'yle taşıdığı benzerliklerden dolayı, onun da mitsel açıklamadan uzak bilimsel bir tavrı olduğu kanaatinin yerleşmesine neden olmuştur.

$\mathrm{Bu}$ özelliklere dayalı olarak da başta Miletli filozoflar olmak üzere Antik Yunan felsefesi, hem felsefi düşüncenin özelliklerinin belirlenmesi için model olmuş hem de aynı kaynak özelliklere bağlı olarak felsefenin işlevleri belirlenmiştir. Nietzsche'nin "uygarlık dahilindeki felsefenin" işlevleri görüşü de bunu desteklemektedir. Nitekim o, felsefenin dört işlevinden bahseder ve bu işlevler aynı zamanda Antik Yunan'da felsefenin diğer düşünce tarzlarından ayırt edici olarak ortaya çıktığı düşüncesine ilişkin diğer yorumlarla da tutarlıdır: "1. Mit öğesini bastırmak 2. Gayreti bilmeye yöneltmek 3. Dinde, ahlakta ve bilimde katı dogmatizmi yıkmak 
4. Körü körüne dünyevi eğilimi yıkmak” (Nietzsche 2018, 90).

\section{Felsefe İçin Özgür Ortam}

Felsefenin Milet'te başlama nedenlerinden biri olarak, felsefenin yeşerebilmesi için özgür bir ortama gerek duyulduğundan ve bu ortamın da Milet'te bulunduğundan bahsedilir. Burada bir genellemeye dikkat çekmekte fayda vardır: bu genelleme Milet Okulunda başladığı söylenen felsefenin, bütün bir Antik Yunan'a mal edilmesidir. Dolayısıyla, felsefenin ortaya çıkışına imkân sağlayan özgür ortam da sadece Milet'e değil bütün bir Antik Yunan coğrafyasına aitmiş gibi algılanır. $\mathrm{Bu}$ noktada Karatani, ayrı bir belirlenime yönelir. Ona göre felsefenin kaynağındaki Milet'in ayırt edici özelliği geleneklerinden kopmuş göçmen kenti olmasıdır (Karatani 2018, 29-30). Dolayısıyla bu özellik bütün bir Antik Yunan'a has değildir. Karatani'nin bu görüşünü Antik Yunan'daki sürgün ve Sokrates örneğindeki gibi ölüm cezası örnekleri desteklemektedir. Bununla birlikte köklerinden uzaklaşılan ve uzlaşıma dayalı yeni bir ortamda bu düşünürlerin ortaya çıkmış olması da felsefe için özgür ortam gerekliliğini desteklemektedir. Nitekim Antik Yunan dediğimiz monarşiden sınıfsal demokrasiye kadar çeşitli yönetim biçimlerini ve farklı toplum özelliklerini bünyesinde bulundurmaktadır. Dolayısıyla dönem olarak bakıldığında filozofların özgür ortamda fikir ürettikleri gibi, dogmatik ve despot nitelikli ortamlarda da bedeli ne olursa olsun fikir ürettikleri görülmektedir. Peki bu durumda felsefe için özgür ortam gereklidir önermesi neyi yansıtmaktadır?

Yukarıda belirttiğimiz Nietzsche'nin felsefenin işlevleri olarak belirlediği unsurlar, esasında koşullar ne olursa olsun "belirlenmemek"le alakalı gibi görünmektedir. Başka bir ifadeyle, koşulların yarattığı bir özgürlükten ziyade, filozofun düşünme eyleminde koşullardan belirlenmemesini yani koşullardan bağımsız olarak düşüncenin özgür olmasıdır. Dikkat edilirse bu işlevler sadece dini ve siyasi dogmaları işaret etmemekte aynı zamanda bilim dâhil bütün alanlarda dogmatizmin karşısında yer almaya işaret etmektedir. Haliyle felsefe için siyasi ya da yönetimsel bir özgür ortam zorunluluğundan ziyade filozofun her koşulda özgür tavrı ön plana çıkmaktadır ki bu durum da felsefe tarihinin farklı noktalarındaki örneklerle tutarlıdır. Sonuç olarak karşımızda belirlenmesi gereken bir özgürlük durumu durmaktadır. Rasyonel düşüncenin özgürlükle birlikte ele alınışının belki de en sistemli örneği Hegel'in (1770-1831) felsefe tarihine bakışında karşımıza çıkmaktadır.

Hegel, özgürlük durumunu "akıl" meselesi ile temellendirir. Ona göre akı1, kapasite boyutuyla ele alınabilir. Bunlardan birincisi kendinde-varlık, ikincisi ise kendisi-için-varlıktır (Hegel 2018, 39). Hegel'e göre "kendinde olanın insanlık için nesne haline gelmesi, bilince ulaşıp böylece insan için olması gerekir" ve bu gerekliliği oluşturan süreçte "akıl, kendi kendisinin nesnesi" haline gelir (Hegel 2018, 40). Kendinde varlık formundan kendi-için-varlık formuna geçiş Hegel'e göre "dünyanın tarih içindeki gelişiminde çeşittiliği” meydana getiren şeydir. Bu çeşitliliğin aklın kapasitelerinin dönüşümüne dayalı ortaya çıkışını, özgürlük ve esaret ikileminde ortaya çıkışını şöyle anlatır:

"Tüm insanlığın doğal olarak rasyonel olmasina ve özgürlügün de bu aklın dayandĭ̆ $\mathrm{l}$ hipotez olmasına karşın gene de birçok halkın sürdürmüş olduğu köleliğin varolmuş olmasinı ve halen de kismen varolmasinı ve insanlarin bundan rahatsizlık duymamasinı bir tek bu açıklamaktadır. Bir yanda Afrikalılarla Asyalılar ve diğer yanda Grekler, Romalılar ve modernler arasındaki biricik ayrım, ikincilerin özgür olduklarını biliyor olmalarıdır ve bu onlar için belirtiktir, oysa diğerleri özgür olduklarını bilmeksizin ve dolayısıyla da özgür olarak varolmaksızın böyledirler" (Hegel 2018, 40). 
Hegel'in sözlerinden de anlaşıldığı üzere, akıl ve özgürlük arasındaki ilişkinin tarihe yansımasında, bütün mesele aklın özgürleştirici boyutunun yarattığı farkındalıktır. Yine Hegel'in bu özgürlük durumunu kültürler arası farklılığın kaynağı olarak da görmesi önemlidir. Bilhassa kültürlerarası çalışmalar, bazı toplumlarda meydana gelen bilimsel ve teknik ilerlemelere mukabil, değişen ve ilerleyen, bireyi ve bireyin özgürlüğünü öne çıkaran bakış açılarının, Batı olarak belirlenen taraf ve "ötekiler" farkını nasıl yarattı̆̆ı önem arz eden bir konudur. Hegel'in çalışmalarına da yansıyan bu konunun pratikte G.M. James'i yaratan boyuta nasıl evrildiği ise yine hem felsefe tarihi hem de diğer disiplinler tarafından ele alınması gereken başka bir konudur.

\section{Felsefe İçin İnançtan Bağımsızlaşma}

Miletli filozofları felsefenin başlangıcına ve modern manada düşüncenin kaynağına koyma sebeplerimizden birisi olarak düşüncenin inançtan bağımsılaşması hemen hemen bütün felsefe tarihçilerinin hemfikir olduğu bir konudur. Onların içinde yaşadıkları dönemde, evrene yönelik mitsel, inanca dayalı açıklamalarla yetinmeyip, gözlem ve akılla belirlenmiş bir tavra sahip oldukları ön plana çıkmaktadır. Ancak burada Miletli filozofların içinde yaşadıkları çağdan ya da inanç öğesinden tamamen arınmış olduklarını ya da bunu yadsıdıklarını söylememize imkân verecek bir veri elimizde bulunmamaktadır. Nitekim Thomson'a göre “..Miletos felsefe okulunun kurucularl olan Thales ve Anaksimandros da eski bir rahip-krallar ailesinden geliyordu" (Thomson 1997, 149).

Tıpkı bu filozofların, dinden bağımsız ya da tanrıtanımaz olduklarını destekleyecek veriye sahip olmadığımız gibi tersi de geçerlidir. Dolayısıyla bu filozoflarla ilgili olarak inanç dünyaları hakkında söylenecek her şey bir spekülasyon özelliği taşıyacaktır. Ancak bu filozofların inançtan bağımsızlaşmayla belirlenmesinin de bir arka planı vardır. Bu noktada Miletli filozoflar, esasında bir simgeye dönüşmektedir. Bu simge felsefi ve bilimsel düşüncenin ancak ve ancak inanç sistemlerinden bağımsız hale gelindiğinde ortaya çıkabileceğine dair görüşün bir neticesidir. Bu görüş de elbette tartışmalıdır ve tıpkı felsefenin başlangıcına ilişkin görüşlerde olduğu gibi, dayandığı bazı özel durumlar ve yorumlar söz konusudur. Felsefe-Din ya da Bilim-Din ilişkileri bilhassa modern dünyanın en çok tartıştığı konular arasında yer almaktadır. Bu tartışmaların kökeninde ise iki temel kaygı tespit etmek mümkündür. Bunlardan ilki insan düşüncesinin evrimini anlamakla alakalı olan kaygıdır. İlkel insandan günümüze uzanan süreçte, insan düşüncesinin nasıl değiştiği ve çevresini değiştirip dönüştüren, değerler yaratan, uygarlıkları ortaya çıkaran süreci anlama kaygısıdır. Bilhassa yazılı kaynaklar açısından bakıldığında Miletli filozoflara kadar, dinsel düşüncenin hâkim olduğu, pratik hayat, değerler ve hatta bilimin gelişiminin de bu hâkimiyet altında gerçekleştiği bilinmektedir. Bu bir ilerlememe durumunu ifade etmemektedir. Ancak iktidar sistemleriyle birlikte pratik kaygıları ortadan kaldırmaya yönelik bir gelişim söz konusudur. Bu konuda verilen en iyi örnek her zaman Mısır örneğidir. Bu pratik boyutundan başka bir de doğaüstü ile ilgilenen ruhban ya da "büyücü" sınıfın etkisi söz konusuydu. Bu sınıfın yorumlanmasında da iki boyutlu bir değerlendirme karşımıza çıkmaktadır.

Bunlardan ilki elbette, insan iradesini, doğaüstü güçlerin ve/veya yönetici zümrenin iradesi karşısında sınırlanması durumudur ki, bu durum düşünce tarihinin ilerleyen aşamasında yarattığ Batı Ortaçağıyla belki de en ciddi yüzleşme noktası olarak karşımıza çıkacaktır. Ancak ikinci boyut, Ronan'ın (1920-1995) işaret ettiği ve bu ilkel tarzla ilkel bilimin bir arada ilerlemesine imkân sağlamış olan boyuttur:

"Büyücü, doğadaki genel ilişkiler hakkında çok ince bir anlaylşa sahip olabilirdi. .....çeşitli maddeler hakkında deneme ve gözleme dayalı bir takım bilgilerin toplanmasını sağladı..... ancak zamanla, başarılar ve 
başarısızlıklar, hangilerinin gerçekten etkili, hangilerinin etkisiz olduğunu gösterecekti. .....büyücü deney yapan araştırmacılar soyunda ilk sirayı aldı ve modern bilim adaminin atası oldu...." (Ronan 2003, 6).

Ronan'ın da ilerleyen kısımlarda belirttiği gibi, bu tarz pratik çalışmalar ve araştırmalar evet bir tür pratik bilgiyi ortaya çıkarmaktaydı ancak bu bilgi, animistik bir inanç dünyasına sahip halkın karşısında konumlanmış bir grubun tek elindeydi (Ronan 2003, 7-8). Bu durum pratik kaygılar neticesinde büyük keşiflere imza atmış olan Antik Mısır'da, rahiplerin sahip olduğu özel bilgiyi ifade eden Gizemler Sistemi'yle de örtüşmektedir. Yukarıdaki bölümlerde bahsettiğimiz Monah James'in Çalınmış Miras eseri de, Misır Gizemler Sistemi'nin Antik Yunan'a aktarılmış olduğu argümanı üzerine kurulmuştu. Ancak onun da kabul ettiği gibi, bu sisteme ait bilgiler bir tür Gizem'i ifade ettiği için yazılı kayıtları tutulmuyor ve rahiplere sözlü olarak aktarılıyordu. Bu da Ronan'ı desteklediği gibi, Giriş bölümünde Miletlileri ayırıcı özelliklerden biri olan, kamuya açık yazılı geleneğin düşünce tarihi açısından önemini gösteriyor.

Yine inanç sistemleriyle bağlantılı ikinci boyut ise, Batı felsefe tarihçilerinin, kendi tarihi köklerinde yer alan ve Aydınlanma sürecinde ciddi bir hesaplaşma sürecine tanık olduğumuz, Ortaçağ Hristiyan düşüncesinin etkisidir. Bildiğimiz üzere Ortaçağ ardından Rönesans'1 getirmiştir. Rönesans yani "yeniden doğuş". Hristiyan öğreti ile belirlenen ve düşünce dünyasından belki de daha çok sosyal hayatta yansımalarını gördügümüz bu dönem, Batı dünyası için bir hesaplaşma noktasıdır. Tek sesli ve metafizik sorunlarla meşguliyeti eleştirilen ve yüzleşilen bir dönem tasviridir. Ancak bu yüzleşmenin felsefi problemlerin sadece Hristiyan öğretiyle belirlenmiş olması, bilim yerine metafizik problemlere ve insan doğasını sınırlandırıcı, vahye dayalı ahlak öğretilerine yönelimin bir neticesi olarak okumak yeterli değildir. Çünkü bu dönem bilimsel ilerlemede bir yavaşlamayı ifade ettiği kadar, inanç sistemleri üzerinden dini kurumların halk üzerindeki etkisi ve yaptırımının da bir örneğidir. Nitekim söz konusu dönem engizisyonun etkinliği, yöneticiler ve dini kurumlar arasındaki ilişkinin sonucunda halkın fakirleştiği bir dönem şeklinde bilinmektedir. Dolayısıyla bu sistemi değiştirecek, düşünceyi metafizikten ve dinden uzaklaştıracak, her alanda çeşitliliği sağlayacak bir "yeniden doğuş"a ihtiyaç duyacaktır. Başka bir ifadeyle, "din" çeşitliliğin ve insanın hür iradesiyle yapabileceği her türlü yaratımın önünde bir engel şeklinde algılanmaktadır. Burada dikkat çeken şey, Antik Yunan'da inancın yadsınmasından ziyade, insan zihninin üretimine imkân veren çeşitliliği destekleyici bir ortamın bulunmasıdır. Önceki bölümde Nietzsche'nin Yunan filozoflarının çeşitliliğinden bahsettiğini belirtmiştik. Nietzsche'nin Antik Yunan düşüncesine yaklaşımında Pre-Sokratik filozofların çeşitliliğine imkân sağlayan iklimin övüldüğünü görmekteyiz. Bu çerçevede baktığımızda Miletli filozoflar ve felsefenin başlangıcına ilişkin de inanç öğesi, bağlayıcılığı azaltmakla birlikte düşünülmüş gibi görünmektedir. Ortaçağ Hristiyan dünyasına yönelik menfi yaklaşıma karşı Pagan inançların hâkim olduğu bir dönemin çeşitliliğinin tercih edilmesi de sanki sorunun kaynağında ya da felsefe-din, din-bilim ilişkisindeki tutumun kaynağı tek tanrılı sistemler -hatta doğrudan Hristiyanlık ve Kilise- ve bunların tek tipleştirici etkisiymiş kanaatine ulaşmamıza neden olmaktadır. Hatta bu kaygının etkisi Ernest Renan'a (1823-1892) kadar uzanmış, belki de bu kaygı Renan'da dinin karşısında bilimin yer aldığı daha sistemli bir yaklaşımın doğmasına neden olmuştur:

"Kitapta bir de, eski Katolikliğin kalıntıları, ortaçă̆ın ilk yarısında olduğu gibi mecburi ve cihanşümul bir dinin hükümran bulunduğu iman çağlarının tekrar dirileceği yolunda fikirler, kökleşmiş bir halde görülecektir. Allah bizi böyle bir kurtulma tarzından korusun! Iman birliği yani taassup dünyada ancak eski günlerin cahilliği ve kolay inanmastyla yeniden doğabilir. Bir millet mutaassıp olacă̆ına ahlaksız 
olsun daha iyi, çünki ahlaksız insan toplulukları rahatsızlık vermedikleri halde mutaassip insan toplulukları dünyayı hayvanlaştırırlar, hayvanliğa mahkum bir dünya ise kendisiyle ilgilenmeye değmez" (Renan 1965, X).

$\mathrm{Bu}$ noktada felsefe tarihi de genel tarih bilgisinden ve insanoğlunun maziyle hesaplaşmasından, doğal olarak etkilenmiş görünmektedir. Hristiyan Ortaçağa karşı bu hesaplaşma, beraberinde her türlü metafizik unsuru yadsıyan görüşleri getirmiştir ki, ilkçağ filozofları bu nokta da mitler karşısında "ilk fizikçiler" olarak övülmüşlerdir. Materyalist bir bakış açısıyla Cogniot (19011978) bu durumu fiziğin masalın yerini alması olarak ifade ederken (Cogniot 1992, 16), Abel Rey'den alıntı yaparak bu tavrı "devrimci bir olay" şeklinde nitelendirmektedir: "O zamana kadar masalın, mit'in yeterli olduğu yerde bu her şeyi kavramak iradesi 'çok devrimci' bir şey, 'çok müthiş bir olay' idi”' (Cogniot 1992, 20). Söz konusu bakış açısı da tıpkı Ortaçağ sonrası bilimsel gelişmelere yaklaşımları anımsatmaktadır. Nitekim Descartes'in düalist töz anlayışı, ruhun empirik bilgiye konu olamamasından dolayı, sonraki yüzyılda maddenin lehine bir monizme dönüşerek Fransız Materyalizmine kaynaklık etmiştir. Emprik geleneğin de etkisiyle, 18. yüzyılda Fransız düşüncesinin belirleyicisi olan mateyalizmin genel karakteristiği dinsel ve metafizik öğelerin elenmesi ve evreni sadece madde ve maddi süreçlerle açılayan özelliğidir, dolayısıyla epistemolojik olarak doğa bilimleri eğiliminin baskınlığı söz konusudur ki bu da 19 . yüzyıl ve devamında pozitivizmi beraberinde getirecektir. Batı felsefesi tarihi çalışmalarının özellikle 19. yüzyılda ivme kazandığı da göz önünde bulundurulursa, felsefenin başlangıcına ilişkin düşüncenin inançtan arınmış olma özelliğinin koyulması dönem tavrının bir neticesi olacaktır. Nitekim Zeller bu konuda, "her halk felsefe ortaya koyabilmiş midir?", "Antik Yunan dışında başka halklarda felsefe var mıydı?" sorusu çerçevesinde inceleme yaparken, Hintlilerde çeşitli felsefelerden bahsedilebileceğini ancak bunların hiçbir zaman dinle bağlarını kesmedikleri ve müstakil bir hüviyete kavuşamadıkları sonucunu çıkarmaktadır (Zeller 2017, 30). Din için söz konusu olan durum Milet ve diğer Antik Yunan düşüncesindeki bilimsel tavır için de geçerlidir.

\section{Miletli Filozoflar ve Bilim-Teorik Bilgi}

Her türlü inanç öğesinden bağımsız evreni kavrama çabası şeklinde algılanan Miletli filozoflar, inançtan arınmış düşüncenin gözlem ve akla dayalı çalışma prensibiyle birlikte aynı zamanda "ilk fizikçiler" unvanını da alarak, modern bilimin de kaynağına yerleştirilmişlerdir. Yine bir ayırt edici özellik olarak, Milet’te bilgiye yönelimin, pratik kaygıların, gündelik hayatı ve yaşamı idame ettirmenin bir gereği olarak değil, salt bilme isteğiyle teoriye yöneldiği belirtilir. Yine bu yoruma imkan sağlayan da Miletli filozofların kendinden öncekilerle ve diğer coğrafyalardaki bilme etkinliğinin niteliğiyle kıyaslanmalarıdır. Ronan durumu böyle yorumlayanlardandir:

\footnotetext{
"Benzer bilgileri sir olarak veya başka şekilde elde bulundurmak, yüksek sosyal mevki işaretiydi. Bu durum, daha sonraki bazı toplumlarda, örneğin Yunan toplumunda, bilimin pratik, elle yapılan denemeye dayalı yönüne nazaran, onun entelektüel yönüne çok daha büyük önem vermesine neden oldu" (Ronan 2003, 8).
}

İlk fizikçiler denilen Miletli filozofların da kendilerinden öncekilerden etkilendiği aşikardır. Nitekim, yukarıdaki bölümlerde de belirttiğimiz gibi, bilim tarihçileri, bugün anladığımız manada bilime gelene kadar, insan düşüncesinin deneyin, deneme-yanılmanın birçok evresinden geçtiğini kabul etmektedir. Hatta yine daha önce değindiğimiz gibi, bu deneme yanılmalar bilimsel tavra atalık yapmakla birlikte, belirli zümrelerin elinde ve hatta dinsel ayinlerin parçası niteliğindedir. İște Miletlilerle ilgili hemfikir olunan noktada burasıdır. Miletli filozoflar, hem 
evren hakkında gözleme dayalı bir düşünme biçimine sahiptirler hem de bu kamuya açık bir bilgidir. Yine onları diğerlerinden ayırt eden diğer bir özellik ise, hem kendilerinden öncekilerden elde ettikleri bilgileri hem de kendi fikirlerini teorik bir boyuta taşımalarıdır:

“...ilk fizikçiler, Anaksimandros ve Anaksimenes Miletoslu Thales'in
ögrencileridir; Thales Lydia'dayken Mezopotamyalı din adamları
sayesinde 28 Mayls 585 'teki güneş tutulmasın önceden haber verebilmişs
ve doğmakta olan matematiği tantmlayan ve belirleyen ilişkilerin
geometrik şekilleri arasındaki benzerlik ilişkilerine eğilebilmiştir”
(Dumont 2007,7-8).

Anlaşılacağı üzere Milet dışında ve hatta Milet'i etkilemiş ya da bazı düşüncelere kaynaklık etmiş görüşler ve bilgiler mevcuttu. Peki neden Milet bilimsel bilginin kaynağı olarak yorumlandı. Tuncar Tuğcu'ya göre Thales'in çağdaşları olan Lao Tzu, Buda, Konfüçyus, İşaya ve Zerdüşt'ün de "bilimin ve felsefenin ana sorunlarını çözmeyi denemişler", bunlardan hareketle evreni açıklayan bilgi, ahlak sistemleri geliştirmişer, hatta kendi halkları ve diğer halklarda etkili olmuşlardır (Tuğcu 2000, 13-14). Ancak Thales'i ve Milet Okulunu çağdaşlarından ayıran şey, bilgiyi elde etmede bir devamlılı̆̆ın olması ve bu sürecin tesadüfi olmaması şeklinde açıklamaktadır. Yani Tuğcu'ya göre bilimin merkezinde İyon coğrafyası ve Thales'in olmasının nedeni, bu coğrafyada üretilen bilimsel bilgi yaşamla iç içeriğini korumuş ve bir süreklilik kazanarak, bir filozoflar silsilesi meydana gelmiştir, bu da "Thales'in tarihsel bir rastlantı olmadığını göstermektedir" (Tuğcu 2000, 14).

$\mathrm{Bu}$ filozofların fiziksel dünyayla ilgilenmiş olmalarına ve bilhassa din konusundan uzak kalmış olmalarına dair kanaatin sebebi de yine elimizdeki ilk kaynaklardır. İyon felsefesinin

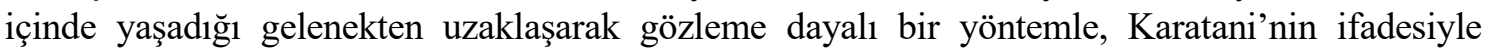
"bugünün birçok bilim insanına benzer biçimde" tasvir edilmesinin kaynağında da "Atinalı filozoflar, Platon ve Aristoteles”ten kalan eserlerden edindiğimiz yargı vardır (Karatani 2018, 25).

Ancak ilk filozofların modern düşünürler tarafindan yorumlanışı bununla kalmamış, aynı zamanda modern bilimsel düşünceyle benzerlikleri de ön plana çıkarılmış, hatta modern bilimsel tavrın ataları olarak övülmüşlerdir. Batı Ortaçağında, dine aykırı düşüncelerin yasaklanması, bilimin gelişiminin önünde bir engeldi. Ortaçağda kilisenin bu tavrı ve yarattığ 1 sonuçlar, sonraki süreçte, o döneme ilişkin bir değerlendirmeyi beraberinde getirdi. $\mathrm{Bu}$ değerlendirmelerin bir sonucu ve toplamı olarak karşımıza Aydınlanma Çağı geldi. Elbette Aydınlanma düşüncesi içerisinde birçok unsuru ve faktörü barındırmaktaydı. Ancak bizim konumuzla ilgili aşikâr olan şey, din karşısında, rasyonel düşünce ve bilimsel düşüncenin yüceltilmesidir ki bu tavır sonraki asrın yorumlama ve tarih yazıcılığını belirlemiştir. Burada gözden kaçırılmaması gereken bir hususa dikkat çekmekte fayda vardır: Söz konusu tarihlerde din, bugün bilimsel incelemelere konu olan, tarihi, insan hayatındaki etkileri araştırılan, insan neden inanır sorusu ya da bir dine neden ihtiyaç duyar vb sorularına konu olan bir "olgu"dan ziyade, Kilise özelinde vücuda gelmiş bir "özne” gibi algılanmaktadır. Çünkü Kilise özelindeki uygulamaların fikri hayatta olduğu kadar sosyal hayatta da sonuçları olmuştur. Dolayısıyla bu sonuçların dolaylı etkisinin felsefe tarihçiliğini ya da felsefenin gelişimi üzerine okumaları da etkilediğini söylemek yanlış olmayacaktır. Sonuç olarak, felsefe daha tümel bir bilgi türünü ifade edip, insan eylemlerinin değerinin bilgisini ve pratiğini de konu edindiği halde -inanç dâhil-, bilimi olumladığı gibi inancı insan eylemlerinde yadsıyan bir felsefe başlangıcı, "İlk filozoflar, ilk bilim adamları örnekleri oldukları için mi değer kazandılar?” sorusunu akla getirmektedir.

\section{Sonuç ve Tartışma}

Felsefe, düşünce temelinde hem teorik hem de pratik yönü olan bir etkinliktir. Felsefenin 
başlangıcı söz konusu olduğunda, hemen hemen bütün kaynaklar Milet Okulu konusunda hemfikirdir. Bu başlangıç fikrinde ön plana çıkan ana belirlenim unsurları ise, yazılı kültür, düşüncenin din ya da inançla ilişkisi, sistematik düşüncenin görünürlüğü ve fillozoflar silsilesi, yani düşünsel faaliyetin devamlılı̆̆g gösterilmektedir. Ancak bu belirlenimler belirli bir dönemin bakış açısından ve o dönemin şartlarında makul olmakla birlikte, günümüz koşulları açısından geçerliliği tartış1ır kanaati hasıl olmuştur.

Öncelikle felsefenin evrene, hayata, insana yönelik bir merakla başladığı fikrini paylaşmakla birlikte, bu merakın tarihin belirli bir döneminde, belirli bir coğrafyada, diğer zaman-mekan koşullarından farklı olarak ortaya çıktığını kabul etmek zordur. Çünkü Aristoteles'in de tespit ettiği gibi "insan, doğal olarak bilmek ister". Bu bilme isteği ya da arzusunun özsel olduğu düşünüldüğünde -ki bizce öyledir- bunun kayıtlı olmayan tarihlerde de insanda olduğunu düşünmek gerekir. $\mathrm{Bu}$ ise felsefe için gerekli olan bilme isteği ve merakın çok eski tarihlerde başlamış olması anlamına gelir ki, bu tarz bir bakış açısı mitolojik açıklamaların kaynağındaki şeyin de bir tür felsefi düşünce olduğunu söylememize imkân verebilir. Peki bu noktada Milet hangi özelliğiyle diğerlerinden ayrılabilir? İnsan zihninin inanç yaratımlarıyla somut olana yönelmesi arasında bir ara form olduğu söylenebilir. Ancak bu da yine yazılı kaynaklarla elde ettiğimiz bir veri olmasından dolayı, daha öncesine ilişkin bir dünya görüşleri silsilesi ya da çeşitliliği yapmış kültür olup olmadığı ya da felsefe diyebileceğimiz düşünce tarzlarının olup olmadığı, Milet örneğiyle aynı şekilde, değerlendirilememektedir. Ancak Milet Okulu filozoflarının somut olana yönelmesi ve gözlemi ön plana çıkardıklarını söyleyebileceğimiz bir sistem inşa etmiş olmaları, özellikle bilgiyi "bilimsel bilgiyle" eş değer tutan yaklaşım tarzında değer görmüş görünmektedir. Bu değer atfetme ise felsefe için başka bir krize sebep olmaktadır ki bu krizde felsefe bilimlerin atası olmak açısından değerlidir; ancak bilimlerin özerkliğini ilan etmesiyle birlikte atıl konuma düşmektedir. Nitekim 20. yüzyılın aynı zamanda felsefenin değerinin tartışıldığı bir dönem olması da tesadüfi değildir. Elbette bu tartışmanın öncülünde Aydınlanma Düşüncesi'nin kendinden öncekiyle yaptığı hesaplaşmanın olduğu da aşikârdır ve felsefe tarihi yazımında da kendini hissettirmektedir. Felsefenin değeri tartışması ve Batı Aydınlanma Düşüncesi'nin etkisinde yazılan felsefe tarihi çalışmaları ise önümüze iki yeni problem ve farklı bakış açıları getirir. Bunlardan ilki 20. yüzyıl tartışmalarının içinde gerçekleşir ki felsefenin değeri nedir üzerinde şekillenir. Eğer felsefe, epistemolojik olarak doğrulanabilir bilgiler düzlemi olarak ele alınırsa, bilimler karşısında işlevsiz kalacak ve tarihi değeri olan ama anlamsız ve işlevsiz bir alana dönüşecektir. Eğer bu birincideki evrene yönelik kesin bilgi arayışının ötesinde, hayata ve insana dair bir inceleme, bir anlam arayışı olarak değerli addedilecekse, o halde tarihi kökeninin sistemli bilimsel düşüncenin ilk yazılı örneklerinin ötesinde felsefeye bir başlangıç aramak ve farklı kültürlerde hâsıl olmuş, yazılı olmayan düşünce gelenekleri de dâhil, düşünceleri de içine alan daha geniş bir araştırma alanı açılması gerekecektir. Nitekim, kanaatimce, bugün kültürler arası felsefe çalışmalarını şekillendiren bu gerekliliktir.

Felsefenin başlangıcındaki bir diğer belirlenim yukarıda üzerinde durduğumuz üzere dinfelsefe ilişkisidir. Daha doğru bir ifadeyle felsefi düşüncenin inanç sistemlerinden azade bir insan aklını referans aldığı görüşüdür. $\mathrm{Bu}$ durum Batı düşüncesinin yine Batı kilisesiyle hesaplaştığı bir dönemin yorumu olması olasılı̆̆ , Milet'i mitolojilerin üzerinde, inançlarından sıyrılmış bir rasyonel tavır olarak simgeleştirmek ve hem felsefeye hem de bilime din karşısında kalıcı bir alan belirlemek gayesinin sonucu olabilir. Ancak bu da hem o dönem koşulları ve antikçağ filozoflarının bütünü göz önünde bulundurulduğunda, hem de başta tek Tanrılı dinler olmak üzere, bu dinlere mensup kişilerin filozofların felsefi görüşleri dikkate alındığında, hem de bugün felsefenin alanları içerisine değerler alanı ve dinin de girdiği düşünüldüğünde, dinfelsefe ve din-bilim karşıtlığının felsefe tarihinin başlangıcına kaynaklık etmesi tek yönlü bir 
bakış açısının, görmek istediğini tarihte görmeye çalışması zorlamasının ötesine geçmemektedir. Üst paragrafta belirttiğimiz yazılı olmayan ama bize kadar ulaşmış düşüncelerin ya da Batı düşüncesinin gelişim çizgisinde gerilere attıkları toplumların düşünce yapılarının ve değer dünyalarının incelenmesi, insanoğlunun anlama ve anlamlandırma çabalarının bir bütün olarak kavranmasını sağlayacaktır. Klasik felsefe tarihi kaynaklarında, çağdaş oldukları verilmesine rağmen, bir yaşam tarzı, ahlak öğretisi ya da bir inanç sistemi olduğu belirtilerek, Milet'ten ayrıldıkları ve felsefi çaba içinde değerlendirilmelerinin zor olduğu söylenen Buda, Konfüçyüs, Lao Tzu gibi isimler ve yaşadıkları kültürlerin bir bütün olarak yeniden, yeni tanımlamalar ve koşullarla ele alınması gerekir.

Felsefe tarihinin başlangıcının Milet Okulu olarak belirlenmesi, esasında Modern Batı Düşüncesi'nin başlangıcının belirlenmesi olarak görünmektedir. Modern Batı düşüncesinin akı1 ve bilimle belirlenmesi, düşünceyi dinden ve her türlü inanç sisteminden azade olarak belirlemesi, bilginin değerinin metafizik öğelerden arındırılarak, gözlem ve tecrübenin ön plana çıkarılması ve hatta felsefenin başlatıcı unsurlarından olan Milet'in ticaret geleneği olarak görülmesi ve yönetim sisteminde bir prototip olarak yine Milet'te demokrasinin bulunması tesadüf değildir. Felsefenin başlangıcına ilişkin bu özellikler -ki aksi özellikteki örnekler bu sistemde yok sayılmıştır ve sisteme entegre edilme yoluna gidilmiştir- modern dünyada ideal olarak belirlenen özelliklerin "ilk" örnekleri olarak görülmesi de Batılı düşünce tarihçilerinin dönem idealine bir köken yaratma süreci olarak görülebilir. Bu durum elbette kasitlı olmayıp, dönem zaman-mekân koşullarının düşünce tarihçileri ya da filozoflar üzerindeki etkisinin bir sonucu da olabilir. Nitekim söz konusu tarih, yazarlar açısından spekülasyonlara ve yoğun sübjektiviteye imkân sağlayan bir tarihtir.

Söz konusu problem basit, belki ihmal edilebilir bir detay olarak da görülebilir. Ancak ortaya koyduğu argümanlar açısından bakıldığında etkisinin büyük olduğunu düşünmekteyiz. Söz konusu argümanlar, öncelikle bilimin diğer insani değerlerden azade ve ayrı olduğu gibi hatalı bir algıya neden olmuş görünmektedir. Son yüzyılda tartışılan bilimin değeri ve insanlık tartışmalarının kökeninin, bir bütün halinde "ilk doğa filozofları" ya da "ilk fizikçiler"in diğer değer algılarından -ki inanç sistemlerinin de yarattığ 1 bir değerler sistemi olduğu inkâr edilemez- olarak sunulması ve onların içinde yaşadıkları toplumdan başkalaştıkları algısı hem filozof/bilim adamı ve toplum ayrımının ilk noktası olmakta, dolayısıyla ilk yabancılaşma örneği olarak sunulmakta hem de nesneleşen "öteki” insani alanın yadsınmasına neden olarak sanki bunalıma kaynaklık etmektedir. Başka bir ifadeyle, modern dünyanın bilen insanın yalnızlık duygusu yaygın inanışının modern dünyadaki görüntüsünün ilk kaynağı Milet’te aranmak mıdır? Demokrasinin ve demokratik ortamın felsefe için bir zorunluluk olduğu, felsefenin ancak özgür ortamda yeşerebileceği fikri de yine kaynağını bu tarihlerden almaktadır. Ancak evet Miletli fillozofların başına aksi bir durum gelmemiş olmakla birlikte, Milet'le birlikte genellemesini yaptığımız Antik Yunan dünyasında sürgün ve idamlarla karşılaşmış filozofların da bulunduğu bir vakıadır. Dolayısıyla ortaya çıkan soru şudur: Milet modelinde olduğu gibi felsefe özgür ortama $m ı$ ihtiyaç duyar, yoksa felsefenin doğasında ölümü dahi göze alan bir özgürlük istenci mi vardır? Yine bir başka soru: Özgür ortama ihtiyaç duyan bilim midir, yoksa felsefe midir?

Felsefeyi Milet'te başlatan argümanlardan birisi dinden azade olmak, inanç sistemlerinden olabildiğince siyrılmak olarak görülmektedir. Ancak yine bu kendi yazılan tarihi içinde yanlışlanan bir argüman olarak karşımıza çıkmaktadır. Nitekim Pythagoras örneğinden tutun da Aziz Augustinus'un İtiraflarım eserinin modern düşüncenin kökenindeki bir çok isme kaynaklık etmesi ya da Descartes sonrası bir felsefe olarak felsefe tarihinde yerini alan Malebranche bunun örnekleridir. Bu argümanın ortaya çıkardığı bir diğer problem özelde İslam Felsefesi genelde ise bütün Doğu Felsefeleri açısındandır. Başlangıca bir silsile yaratmadıkları, devamlılıkları olmadığı ve sadece bir yaşam ya da ahlak öğretisi olarak kaldıkları gerekçesiyle 
felsefi olmadıkları varsayılan Mısır Gizemler Sistemi’nin öğretileri ya da Buda, Konfüçyus ve diğer örnekler günümüzde felsefenin yüklendiği anlam itibariyle felsefi olma özelliği taşımaktadır. Özelde İslam felsefesinin durumu ise, felsefenin başlangıcına yerleştirilen felsefi olma özelliklerine dayalı olarak başka bir sıkıntının kaynağıdır. Başta Kindi olmak üzere, dinden azade bir filozof fikrine uymadıkları aşikâr oldukları için, Yunan tarzında felsefe yapan İslam filozofları tanımlaması ortaya çıkmıştır. Ancak bu tanımlamada hem filozof hem bilim adamı yönüyle İbn Sina dahi yukarıdaki özellikleri taşıyamadığı gibi, belirlenen klasik dönem dışında yani Yunan tarzında felsefe özelliği dışında örnek olmadığı düşüncesini yaratmakta ve bir dönem var olmuş sonra bitmiş bir düşünce etkinliği sınırlı bir coğrafya ve zamanla sınırlanmıştır. Bu da zamanın, düşünce açısıdan farklı coğrafyalarda durduğu sınırlı bir coğrafya ve kültür için akmaya devam ettiği izlenimini yaratmaktadır.

Belki de buradaki ana problem, modern düşünceye aradığımız kaynak arayışında Milet'e, Milet'in dahi beklediğinden ve yaptığından daha sıkı sarılmamızdır. Nitekim söz konusu filozoflarla ilgili kaynaklar, doğrudan kaynaklar olmayıp, ikinci ve üçüncü isimlerden kaynaklardır. Elimizde bulunan fragmanlar dahi, tarihsel olarak yakın kaynakların aktarımından ibarettir. Sonuç olarak, yorumlanmış kaynaklar üzerinden yarattığımız bir tarihle ve bir modelle karşı karşıya olup olmadığımızın yeniden incelenmesi gerekmektedir.

\section{KAYNAKÇA}

Aristoteles (1996). Metafizik. İstanbul 1996.

Arslan A. (2002). "Yunan Tarzında Felsefe ve Saf Felsefe Geleneği”. Yay. Yön. Tülin Bumin. Felsefe. İstanbul (2002). 265-280.

Capelle W. (2011). Sokrates'ten Önce Felsefe. İstanbul 2011.

Cevizci A. (2009). Felsefe Tarihi. İstanbul 2009.

Cogniot G. (1992). İlkçă̆ Materyalizmi. İstanbul 1992.

Cornford F. M. (2019). Sokrates Öncesi ve Sonrası. İstanbul 2019.

Diogenes Laertius (2013). Ünlü Filozofların Yaşamları ve Öğretileri. İstanbul 2013.

Dumont J. P. (2007). Antik Felsefe. Ankara 2007.

Dürüşken Ç. (2013). Antikçağ Felsefesi, Homeros 'tan Augustinus'a Bir Düşünce Serüveni. İstanbul 2013.

Elmalılı M. Hamdi Yazır (2015). Kur'ân-ı Kerim Meâli ve Meâli. İstanbul 2015.

Guthrie W.K.C. (1999). Illkçă̆ Felsefesi Tarihi. Ankara 1999.

Hegel G. W. F. (2018). Felsefe Tarihi-Thales'ten Platon'a Grek Felsefesi. İstanbul 2018.

James G. M. (2010). Çalınmış Miras. İstanbul 2010.

Kranz W. (1994). Antik Felsefe. İstanbul 1994.

Nietzsche F. (2018). Platon Öncesi Filozoflar. İstanbul 2018.

Renan E. (1965). Bilimin Geleceği I. Ankara 1965.

Ronan C. A. (2003). Bilim Tarihi. Ankara 2003

Runzo J.\& Martin N. M. (2002). Dünya Dinlerinde Hayatın Anlamı. İstanbul 2002.

Soccio D. J. (2010). Felsefeye Giriş Hikmetin Yapıtaşlart. İstanbul 2010

Störig H. J. (2000). İlkçağ Felsefesi Hint Çin Yunan. İstanbul 2000.

Thomson G. (1997). Illk Filozoflar. İstanbul 1997.

Tuğcu, T. (2000). Batı Felsefesi Tarihi. Ankara 2000.

Zeller E. (2017). Grek Felsefesi Tarihi. İstanbul 2017. 